\title{
PENGEMBANGAN LKS BERBASIS INKUIRI TERBIMBING BERBANTUAN E-LEARNING UNTUK MENINGKATKAN PEMAHAMAN KONSEP PADA SISWA KELAS X SMA
}

\author{
Wimpi Calesta*, Patricia H.M. Lubis, Sugiarti \\ Program Studi Pendidikan Fisika FKIP Universitas PGRI Palembang \\ Jln. Jend. Ahmad Yani Lr. Gotong Royong 9/10 Ulu Palembang, Kota Palembang \\ e-mail":wimpicalesta@gmail.com
}

\begin{tabular}{l|c|c|c}
\hline Diterima 19 Desember 2020 & Direvisi 5 April 2021 & Disetujui 29 April 2021 & Dipublikasikan 10 Mei 2021
\end{tabular} https://doi.org/10.33369/jkf.4.1.51-60

\begin{abstract}
ABSTRAK
Penelitian ini bertujuan untuk menghasilkan LKS yang valid, praktis dan mempunyai efek potensial yang dibuat berdasarkan model pembelajaran inkuiri terbimbing dan berbantuan e-learning yaitu aplikasi blogspot. Metode penelitian yang digunakan dalam penelitian ini adalah R\&D (Research and Development) dengan model ADDIE (Analyze, Design, Development, Implement, Evaluate). Validasi dilakukan dengan 3 orang ahli yaitu ahli materi, bahasa dan desain.Berdasarkan hasil validasi aspek materi memperoleh nilai $88,66 \%$ dengan kategori sangat baik, aspek bahasa memperoleh nilai $86 \%$ dengan kategori sangat baik dan aspek desain diperoleh nilai 90,76\% dengan katgori sangat baik. Hasil angket kepraktisan LKS memperoleh nilai 85,81\% dengan kategori sangat praktis. Dan untuk efek potensialnya dalam meningkatkan pemahaman konsep dengan menggunakan rumus $\mathrm{N}$-Gain memperoleh nilai sebesar 0,87 dengan kategori tinggi. Berdasarkan hasil data tersebut, dapat disimpulkan bahwa LKS yang dikembangkan sangat valid dan praktis serta dapat meningkatkan pemahaman konsep pada siswa.
\end{abstract}

Kata kunci : Pengembangan dan penelitian, LKS, inkuiri terbimbing, e-learning, pemahaman konsep

\begin{abstract}
This research was aimed to produce worksheets that was valid, practical and have potential effects based on the guided inquiry learning model and assisted e-learning, namely the blogspot application. The research method used in this research was R\&D (Research and Development) with the ADDIE (Analyze, Design, Development, Implement, Evaluate) model. Validation was carried out with 3 experts, namely material, language and design experts. Based on the results of the validation of the material aspect, the score was $88.66 \%$ with the very good category, the language aspect got a score of $86 \%$ in the very good category and the design aspect obtained a value of $90.76 \%$ with the very good category. The results of the LKS practicality questionnaire obtained a score of $85.81 \%$ in the very practical category. And for its potential effect in increasing concept understanding using the N-Gain formula, it obtained a value of 0.87 with the high category. Based on the results of these data, it can be concluded that guided inquiry-based worksheets assisted by e-learning are very valid and practical
\end{abstract}

Keywords : Development and research, worksheets, guided inquiry, e-learning, understanding concepts

\section{PENDAHULUAN}

Lembar Kerja Siswa (LKS) merupakan salah satu media pembelajaran yang bisa digunakan untuk membantu siswa dalam menambah informasi tentang konsep yang dipelajari melalui kegiatan belajar yang sistematis.Di dalam LKS selain komponen juga terdapat fungsi dari LKS tersebut yaitu: (1) dapat meningkatkan aktivitas siswa dalam pembelajaran; (2) membantu siswa dalam memahami konsep yang dipelajari; (3) membantu guru dalam mengevaluasi pembelajaran; (4) memudahkan siswa dalam proses pembelajaran; (5) membantu siswa lebih tertarik dalam pembelajaran. Pada umumnya, LKS yang biasa digunakan di sekolah adalah LKS yang dibeli dari agen-agen buku yang belum menggunakan model pembelajaran tertentu dan bahkan tidak sesuai 
dengan kebutuhan siswa disekolah. Biasanya, LKS yang beredar dipasaran hanya berisi ringkasan materi dan latihan soal saja tidak disertai dengan kegiatan yang jelas yang harus dilakukan siswa pada saat pembelajaran. LKS yang sering kita jumpai biasanya, belum disusun dengan menggunakan pembelajaran yang tepat salah satunya yaitu model pembelajaran inkuiri terbimbing, maka dari itu perlu dikembangkan LKS yang berbasis model pembelajaran inkuiri terbimbing dalam kegitan belajar mengajar agar siswa lebih memahami materi yang disampaikan oleh guru dengan mudah.

LKS dengan berbantuan inkuri terbimbing merupakan salah satu model pembelajaran yang menuntut siswa agar lebih aktif (1). Model pembelajaran inkuiri terbimbing adalah salah satu model pembelajaran yang berpusat pada siswa dalam menemukan suatu konsep dan guru hanya berperan membimbing siswa untuk menemukan suatu konsep pembelajaran (2).

Teknologi Informasi (IT) dalam pendidikan dapat dimanfaatkan sebagai media pembelajaran, salah satu nya yaitu pembelajaran berbantuan e-learning. Pemanfaatan e-learning dalam pendidikan bukan hal baru mengingat sudah banyak sekolah-sekolah dalam beberapa tahun terakhir yang sudah menerapkan sistem pembelajaran tersebut untuk menunjang proses belajar mengajar. Dengan adanya pembelajaran berbantuan e-learning diharapkan dapat melaksanakan pembelajaran yang efektif dan dapat meningkatkan hasil belajar siswa sehingga dapat mencapai suatu tujuan pembelajaran. Dengan adanya e-learning dalam media pembelajaran, dapat berfungsi sebagai pelengkap maupun penunjang untuk meningkatkan proses belajar mengajar di kelas sehingga bisa membantu siswa meningkatkan pemahaman materi atau konsep dan juga meningkatkan kegiatan pembelajaran (3).

Salah satu permasalahan yang sering dihadapi oleh guru fisika dalam pembelajaran adalah kurangnya penguasaan konsep dan pemahaman siswa dalam mempelajari fisika tentu hal ini juga berpengaruh terhadap prestasi belajar siswa. Hal ini dapat dilihat dari hasil wawancara dan observasi yang dilakukan oleh peneliti ketika melakukan studi pendahuluan. Dengan menggunakan media pembelajaran berbantuan e-learning diharapkan siswa dapat memahami konsep fisika dengan mudah. Dengan demikian diharapkan LKS berbasis inkuiri terbimbing berbantuan e-learning dapat memudahkan siswa dalam memahami konsep pelajaran yang diberikan guru sehingga siswa tidak mengalami kesulitan dalam belajar, selain itu agar siswa tidak bosan selama pembelajaran berlangsung, dan bisa membuat siswa lebih tertarik dalam mempelajari fisika, karena yang sudah kita ketahui bahwa fisika merupakan mata pelajaran yang sulit dan membosankan dimata siswa yang dipenuhi oleh angka dan rumus sehingga siswa malas belajar fisika dan juga dapat mempersingkat waktu.

Berdasarkan hasil observasi yang dilakukan di SMA Negeri 1 Kikim Selatan terdapat beberapa kesulitan yang dialami oleh peserta didik, hal ini juga didukung dari nilai-nilai hasil belajar peserta didik yang masih banyak kurang dari KKM (Kriteria Ketuntasan Maksimum). Salah satu permasalahan yang sering terjadi adalah kesulitan peserta didik dalam memahami konsep fisika yang disampaikan oleh guru. Banyak faktor yang mempengaruhi peserta didik tersebut kesulitan dalam memahami konsep fisika diantara nya yaitu terjadi karena cara mengajar guru yang monoton, media pembelajaran yang kurang menarik atau juga fasilitas belajar yang belum memadai.

Menurut penelitian sebelumnya yang dilakukan oleh Dewi, Sadia, dan Ristiati dengan judul "pengembangan perangkat pembelajaran IPA terpadu dengan setting inkuiri terbimbing untuk meningkatkan pemahaman konsep dan kinerja ilmiah siswa" mengatakan bahwa perangkat pembelajaran tersebut telah memenuhi syarat validitas dengan nilai rata-rata validasi buku siswa 3.57 dan buku pegangan guru 3,65. Keefektifan yaitu dengan meningkatnya pemahaman konsep dan kinerja ilmiah siswa, hal ini terlihat dari nilai yang diperoleh siswa telah berada diatas KKM yang ditentukan peneliti dengan ketuntasan $100 \%$ (4). Persamaan penelitian tersebut dengan peneliti yaitu sama -sama mengembangkan perangkat pembelajaran dan menggunakan model pembelajaran inkuiri terbimbing serta mengukur pemahaman konsep pada siswa. Sedangkan perbedaannya yaitu pada penelitian tersebut belum menggunakan e-learning sebagai media pembelajaran sedangkan pada penelitian peneliti menggunakan e-learning sebagai media pembelajaran. 
Menurut penelitian Irmayanti dan Nugroho dengan judul "pengembangan media pembelajaran akuntansi berbasis web blog untuk meningkatkan motivasi belajar siswa" mengatakan bahwa tingkat kelayakan media pembelajaran akuntansi berbasis web blog diketahui berdasarkan penilaian dari ahli materi mendapat skor rata-rata 3,68 dengan kategori sangat baik, penilaian dari ahli media mendapat skor rata-rata 2,97 dengan ketegori baik. Media pembelajaran akuntansi berbasis web blog untuk meningkatkan motivasi belajar siswa sebesar 7,14\%, dengan motivasi awal sebesar 71,78\% sehingga mengalami peningkatan sebesar 78,92\% di motivasi akhir (5). Persamaan penelitian tersebut dengan peneliti adalah sama-sama mengembangkan media pembelajaran berbasis blog. Sedangkan perbedaannya yaitu pada penelitian tersebut pada pembelajaran akuntansi dan mengukur motivasi belajar siswa. Sedangkan peneliti pada pembelajaran fisika dan mengukur pemahaman konsep siswa.

Menurut penelitian Wahyudin, Sutikno, dan Isa dengan judul "keefektifan pembelajaran berbantuan multimedia menggunakan metode inkuiri terbimbing untuk meningkatkan minat dan pemahaman siswa" mengatakan bahwa pemahaman siswa meningkatkan dari $60 \%$ siswa yang dinyatakan tidak paham menjadi 5\% siswa yang dinyatakan tidak paham, hasil analisis tanggapan siswa terhadap pengajaran diperoleh rata-rata tanggapan siswa sebelum tindakan sebesar 72,90\%. Setelah tindakan nilai rata-rata tanggapan siswa meningkat menjadi $76,81 \%$ (6). Persamaan penelitian tersebut dengan peneliti yaitu sama-sama menggunakan model pembelajaran inkuiri terbimbing dan mengukur pemahaman konsep siswa. Sedangkan perbedaannya yaitu penelitian tersebut mengukur keefektifan media pembelajaran dan mengukur minat siswa. Sedangkan pada peneliti mengembangkan media pembelajaaran.

Berdasarkan beberapa penelitian terdahulu yang telah dilakukan dapat disimpulkan bahwa pengembangan lembar kerja siswa (LKS) berbasis inkuiri terbimbing berbantuan e-learning untuk meningkatkan pemahaman konsep siswa dapat meningkatkan pemahaman konsep pada siswa dan sangat efektif dan layak untuk digunakan.

Berdasarkan uraian diatas, maka peneliti tertarik melakukan penelitian dengan judul Pengembangan Lembar Kerja Siswa (LKS) Berbasis Inkuiri Terbimbing Berbantuan E-Learning untuk Meningkatkan Pemahaman Konsep Siswa Kelas X SMA. Tujuan dari penelitian ini adalah menghasilkan LKS berbasis inkuiri terbimbing berbantuan e-learning pada materi gerak harmonik sederhana pada bandul yang valid, praktis dan memiliki efek potensial.

\section{METODE PENELITIAN}

Metode penelitian yang digunakan dalam penelitian ini adalah R\&D (Research and Development) dengan model ADDIE (Analyze, Design, Development, Implement, Evaluate). Produk yang dihasikan dalam penelitian ini adalah Lembar Kerja Siswa (LKS) berbasis inkuiri terbimbing berbantuan e-learning dalam pembelajaran fisika pada materi gerak harmonis pada bandul kelas X SMA. Berikut langkah-langkah pengembangan model ADDIE:

\subsection{Analisis}

Langkah awal untuk mengembangkan LKS berbasis inkuiri terbimbing pada materi gerak harmonik pada bandul adalah melakukan analisis kebutuhan dan mengumpulkan berbagai informasi untuk menentukan kemampuan yang diperlukan oleh peserta didik untuk memahami konsep fisika dengan mudah. Pada tahapan ini, meliputi analisis kurikulum yang akan membantu untuk mengetahui kendala apa saja dan kebutuhan apa saja yang diperlukan oleh siswa serta guru fisika dalam pembelajaran fisika disekolah.

\subsection{Desain}

Tahap kedua yaitu desain atau perencanaan. Langkah pertama yang dilakukan oleh peneliti adalah mulai merancang LKS yang akan dikembangkan sesuai dengan hasil analisis yang telah dilakukan sebelumnya. Langkah terakhir, peneliti mendesain bahan ajar LKS berbasis inkuiri terbimbing secara spesifik dan soal tes yang diberikan mengacu pada pembelajaran berbasis inkuiri terbimbing. 


\subsection{Development atau Pengembangan}

Tahap ketiga yaitu pengembangan. Pada tahap ini mulai dilakukan penulisan dan pembuatan draf LKS serta instrumen penilaian LKS. Pada tahap ini juga, peneliti menentukan struktur LKS berbasis inkuiri terbimbing yang akan dikembangkan.

\subsection{Implementasi}

Pada tahap ini dilakukan uji coba pada kelas yang sebenarnya. Tujuannya adalah untuk mengetahui kelayakan LKS ditinjau dari aspek kepraktisan dan keefektifan melalui pengisian angket respon siswa dan tes hasil belajar siswa.

\subsection{Evaluasi}

Tahap terakhir adalah tahap evaluasi. Tahap ini dilakukan untuk menilai produk LKS yang dihasilkan. Adapun keseluruhan langkah pengembangan dalam penelitian ini dapat dilihat pada Gambar 1.

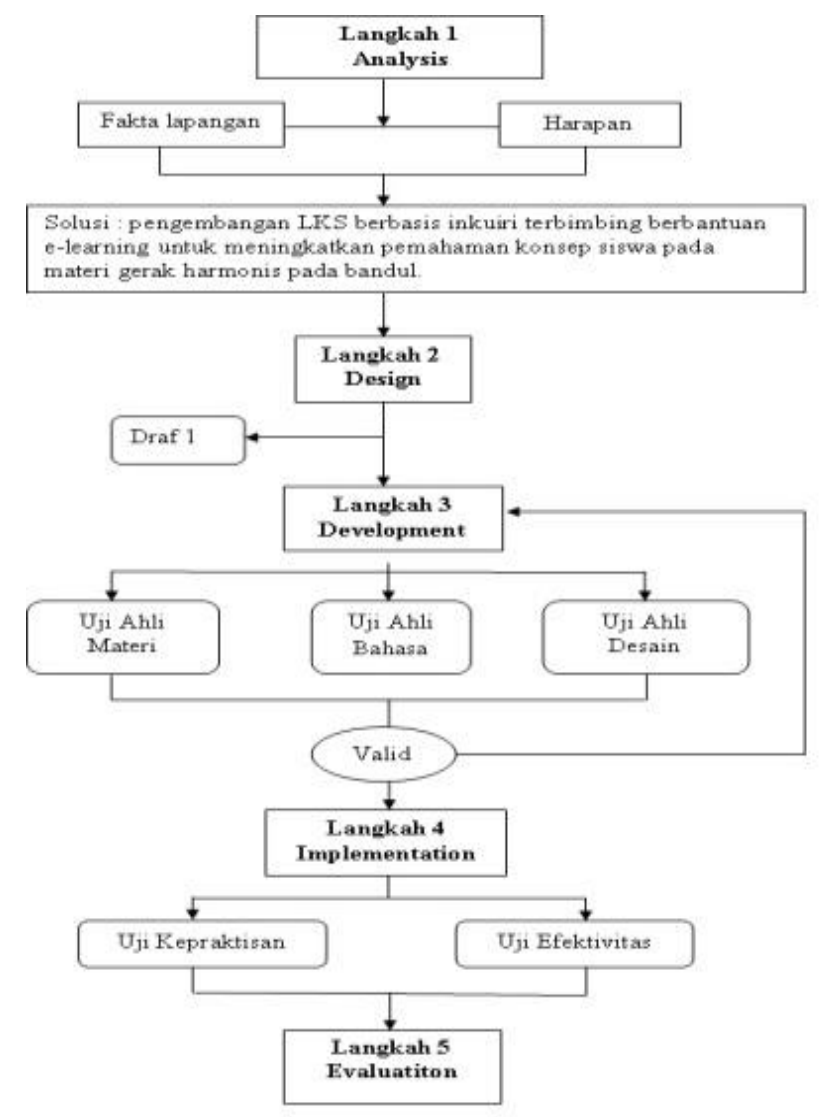

Gambar 1. Langkah-langkah Pengembangan Model ADDIE

LKS yang dikembangkan adalah LKS untuk materi gerak harmonik sederhana pada bandul di kelas X SMA. Uji validitas dilakukan oleh tiga orang ahli yaitu ahli materi, bahasa dan desain dengan menggunakan angket dalam bentuk skala likert. Angket juga digunakan untuk mengetahui respon siswa setelah menggunakan LKS berbasis inkuiri terbimbing berbantuan e-learning dan untuk pemahaman konsep menggunakan rumus N-Gain hasil dari pretest dan postetest.

Lembar validasi yang telah diisi dan diberi nilai oleh ahli/validator, maka selanjutnya dianalisis oleh peneliti untuk melakukan rekaplitulasi skor penilaian. Kemudian peneliti menghitung nilai hasil rata-rata dari validator dengan menggunakan rumus dibawah ini:

$$
\text { nilai validasi }=\frac{\text { jumlah skor yang diperoleh }}{\text { skor total maksimum }} \times 100 \%
$$

Sumber: modifikasi dari Aqib, dkk (7) dengan jumlah skor tertinggi adalah jumlah pertanyaan dikali skor maksimum. Nilai validasi yang telah diperoleh disesuaikan dengan kriteria validasi. Berikut tabel kategori rata-rata aspek yang divalidasi: 
Tabel 1. Kategori Rata-Rata Aspek Yang Divalidasi

\begin{tabular}{cc}
\hline Rata-rata & Kategori \\
\hline$>80 \%$ & Sangat Valid \\
$60-76 \%$ & Valid \\
$40-59 \%$ & Cukup Valid \\
$20-39 \%$ & Tidak Valid \\
$<20 \%$ & Sangat Tidak valid \\
\hline
\end{tabular}

Sumber: modifikasi dari Aqib, dkk (7)

Untuk mengukur pendapat siswa setelah penggunaan lembar kerja siswa berbasis inkuiri terbimbing berbantuan $e$-learning pada materi gerak harmonik pada bandul, angket yang digunakan adalah skala likert. Berikut rumus yang digunakan untuk menghitung nilai rata-rata angket respon siswa:

$$
\text { nilai praktikalisasi }=\frac{\text { jumlah skor yang diperoleh }}{\text { skor total maksimum }} \times 100 \%
$$

Sumber: modifikasi dari Aqib, dkk (7)

Dari rumus diatas, rata-rata nilai dikonversikan ke dalam bentuk deskriptif kualitatif berikut:

Tabel 2. Kategori respon siswa terhadap LKS

\begin{tabular}{cc}
\hline Rata-rata & Kategori \\
\hline$>80 \%$ & Sangat Praktis \\
$60-76 \%$ & Praktis \\
$40-59 \%$ & Cukup Praktis \\
$21-39 \%$ & Tidak Praktis \\
$<20 \%$ & Sangat Tidak Praktis \\
\hline
\end{tabular}

Sumber: modifikasi dari Aqib, dkk (7)

Tes dilakukan pada tahap akhir atau field test yang dig produk yang telah dikembangkan yaitu LKS berbasis inkuiri terbimbing berbantuan e-learning. berikut rumus dan interpretasinya:

$$
N-\text { Gain }=\frac{\text { skor posttest }- \text { skor pretest }}{\text { skor total }- \text { skor pretest }} \times 100 \%
$$

Sumber: Hake (8)

Tabel 3. Kriteria Interpretasi $N-$ gain

\begin{tabular}{cc}
\hline N-gain & Kriteria Interpretasi \\
\hline Nilai $g>0,7$ & $\mathrm{G}-$ Tinggi \\
Nilai $0,3<g>0,7$ & $\mathrm{G}-$ Sedang \\
Nilai $g<0,3$ & $\mathrm{G}-$ Rendah \\
\hline
\end{tabular}

Sumber: Hake (9)

\section{HASIL DANPEMBAHASAN}

\subsection{Hasil}

\subsubsection{Analisis kebutuhan}

Dari hasil analisis yang sudah dilakukan, bahwa bentuk LKS yang dibutuhkan oleh siswa adalah LKS yang dapat membantu dan membimbing siswa dalam menemukan jawaban dari permasalah yang muncul, dan juga yang dapat membantu siswa dalam mengeksplorasi pengetahuannya. Serta dapat membuat siswa menjadi lebih tertarik dalam pembelajaran fisika.

3.1.2 Tahap Desain

beberapa kegiatan yang dilakukan dalam tahap desain ini adalah penyusunan komponen LKS, penyusunan materi, pemilihan media, penyusunan tes, perancangan format LKS yang akan dikembangkan, dan penyusunan instrumen penilaian.

3.1.3 Tahap pengembangan

Berikut langkah-langkah dalam tahap pengembangan. 


\subsubsection{Self evaluation}

Pada tahap ini, peneliti mengkoreksi sendiri disertai konsultasi dengan pembimbing 1 dan 2 terhadap aspek materi, bahasa, desain yang digunakan pada prototype 1 .

\subsubsection{Expert Review}

Tahap Expert Review bertujuan untuk mendapatkan LKS berbasis inkuiri terbimbing berbantuan e-learning prototype 1. Pada tahap expert review validator dari 3 aspek yaitu ahli materi, bahasa dan desain dibuat menjadi satu validator. Hal ini dilakukan untuk melihat dan menilai serta membandingkan hasil validasi dari 3 validator tersebut, untuk mendapatkan LKS yang siap digunakan. Berikut hasil validasi dari 3 validator meiputi aspek materi, bahasa dan desain. Hasil rata-rata LKS yang dikembang setelah dinilai oleh validator memperoleh nilai sebesar $88,66 \%$ pada materi dengan kategori sangat valid, desain memperoleh nilai 90,25\% dengan kategori sangat valid dan bahasa memperoleh nilai sebesar $86 \%$ dengan kategori sangat valid. Berikut tabel hasil rata-rata penilaian LKS oleh validator.

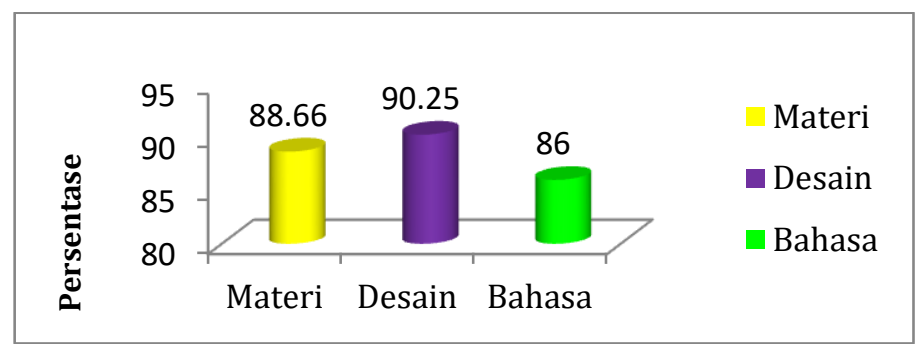

Gambar 2. Hasil Penilaian Validator

Sehingga dapat disimpulkan hasil dari ketiga validator yang meliputi ahli materi, desain dan bahasa bahwa LKS yang dikembangkan sangat valid. Berikut gambaran LKS sebelum dan sesudah divalidasi:

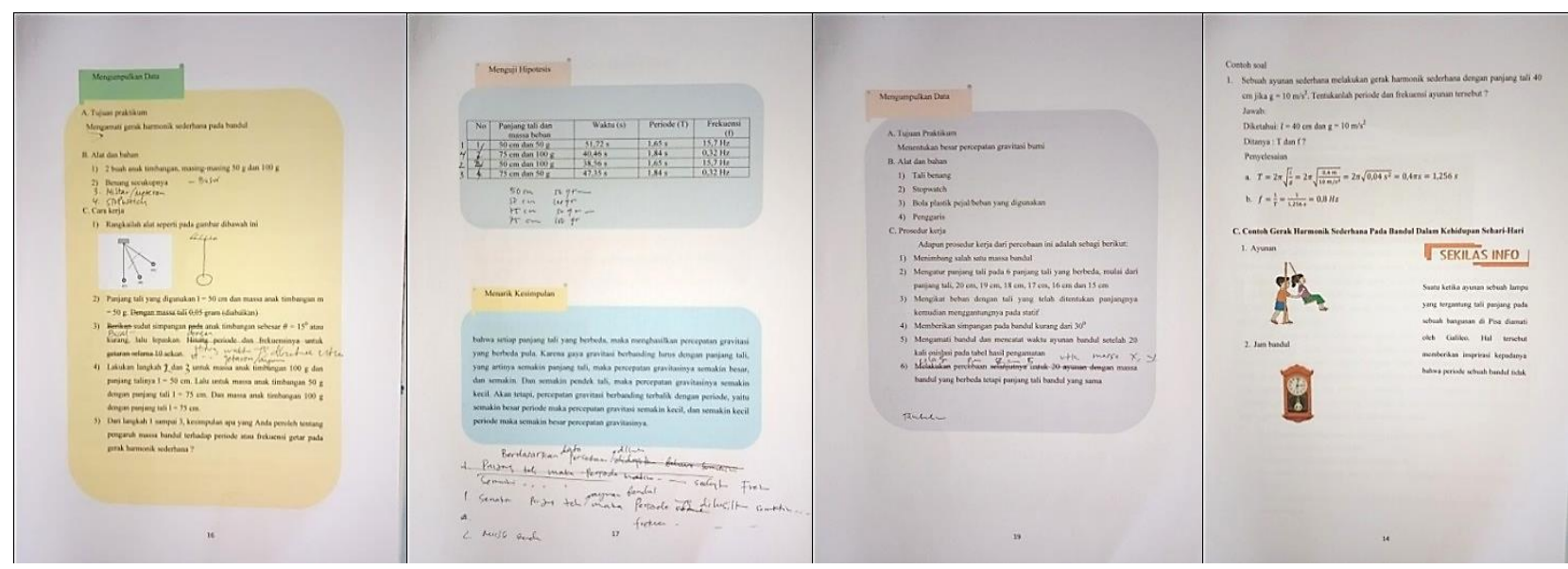

Gambar 3. LKS sebelum divalidasi
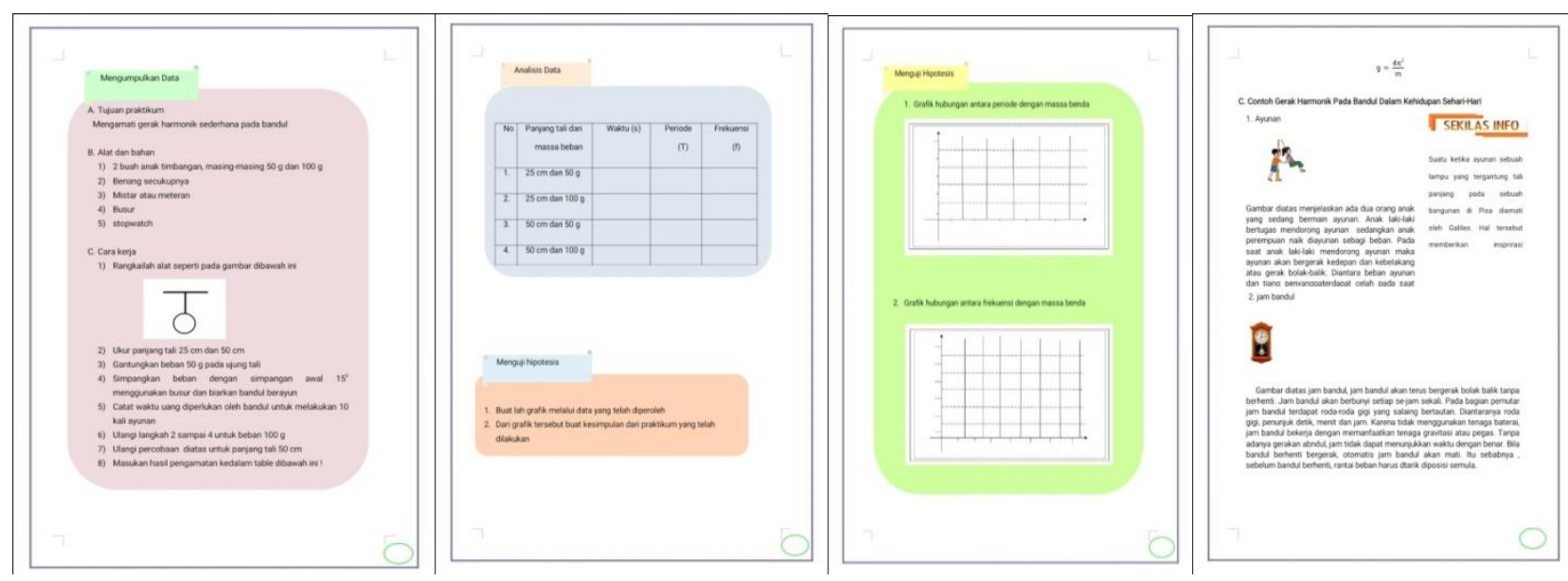

Gambar 4. LKS yang sudah divalidasi

Pengembangan LKS Berbasis Inkuiri Terbimbing Berbantuan E-Learning Untuk Meningkatkan Pemahaman Konsep.... Wimpi Calesta, Patricia H.M. Lubis, Sugiarti 


\subsubsection{One to one (Uji Coba Perorangan)}

Tahap ini dilakukan pada 3 orang siswa kelas X IPA di SMA Negeri 1 Kikim Selatan untuk mengetahui tingkat kepraktisan produk LKS yang dikembangkan. Nilai rata-rata keseluruhan produk LKS pada tahap one to one aspek kemenarikan memperoleh nilai sebesar 96,66\% dengan kategori sangat praktis, aspek kemudahan memperoleh nilai 84,34\% dengan kategori sangat praktis dan aspek keterbantuan memperoleh skor $84,43 \%$ dengan kategori sangat praktis. Berikut grafik hasil one to one.

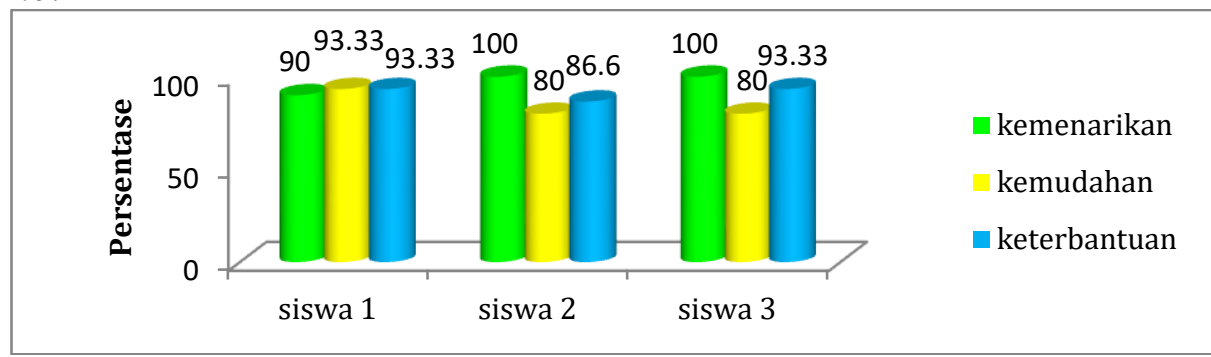

Gambar 5. Hasil one to one

\subsubsection{Tahap Penerapan Produk}

Produk LKS diuji coba dalam kelompok kecil (small group) untuk mengetahui kepraktisan LKS dan juga pemahaaman konsep siswa. Tahap small group ini dilakukan pada 6 orang siswa. Tahap ini untuk mengtahui hasil angket dan pemahaman konsep siswa pada kelompok kecil.

Nilai rata-rata keseluruhan LKS pada tahap small group memperoleh nilai 90,83\% untuk aspek kemenarikan dengan kategori sangat praktis, aspek kemudahan memperoleh nilai $89.99 \%$ dengan kategori sangat praktis dan aspek keterbantuan memperoleh nilai sebesar 92,21\% dengan kategori sangat praktis. Maka dari hasil grafik di atas dapat disimpulkan bahwa hasil kepraktisan LKS pada tahap small group memiliki nilai praktikalisasi yang tinggi dan dapat dinyatakan bahwa LKS yang dikembangkan sudah praktis. Berikut grafik hasil rata-rata pada tahap small group.

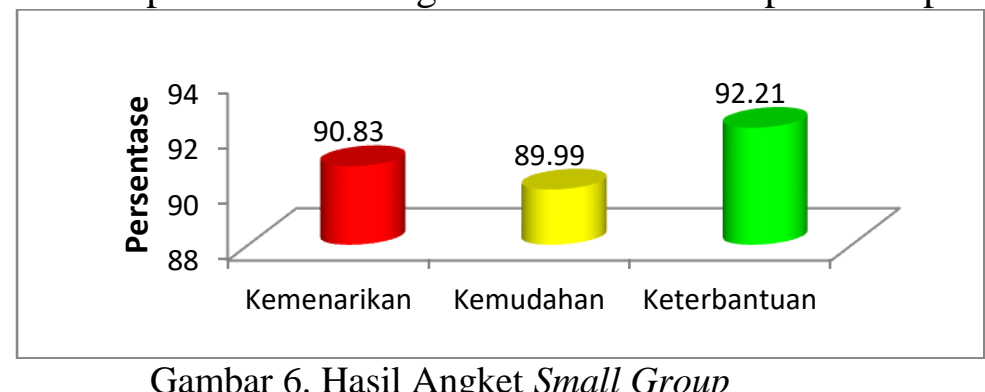

\subsubsection{Tahap Evaluasi dan Field Test (Uji Lapangan)}

Setelah melalui tahap validasi dari validator dan memperoleh komentar serta saran dari teman sejawat dan siswa pada tahap one to one dan small group. Peneliti melakukan revisi lagi dengan mengikuti saran dan komentar yang sudah diberikan untuk menghasilkan prototype ketiga. Pada prototype ketiga ini LKS sudah dianggap memiliki kategori validitas dan praktikalitas. Tahap field test ini bertujuan untuk melihat efektivitas penggunaan LKS berbasis inkuiri terbimbing berbantuan e-learning.

\subsubsection{Hasil Pemahaman Konsep Siswa}

Nilai N-Gain paling tinggi diperoleh sebesar 0,87 dan N-Gain paling rendah diperoleh nilai sebesar 0,6 dengan kategori sedang. Maka dapat disimpulkan bahwa siswa mengalami peningkatan dalam pemahaman konsep. Berikut hasil n-gain pemahaman konsep siswa.

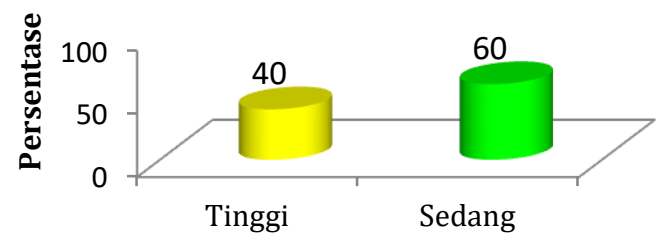

Gambar 7. Nilai N-Gain Pemahaman Konsep Pada Field Test 


\subsubsection{Hasil Angket Siswa dalam Tahap Field Test}

Hasil angket respon siswa terhadap LKS berbasis inkuiri terbimbing berbantuan $e$-learning memiliki jumlah rata-rata $85,81 \%$ dengan kategori sangat praktis. Maka dapat disimpulkan bahwa LKS berbasis inkuiri terbimbing mendapat respon yang posif dari siswa untuk dijadikan media pembelajaran. Berikut grafik hasil angket respon siswa yang dilakukan pada 30 orang siswa:

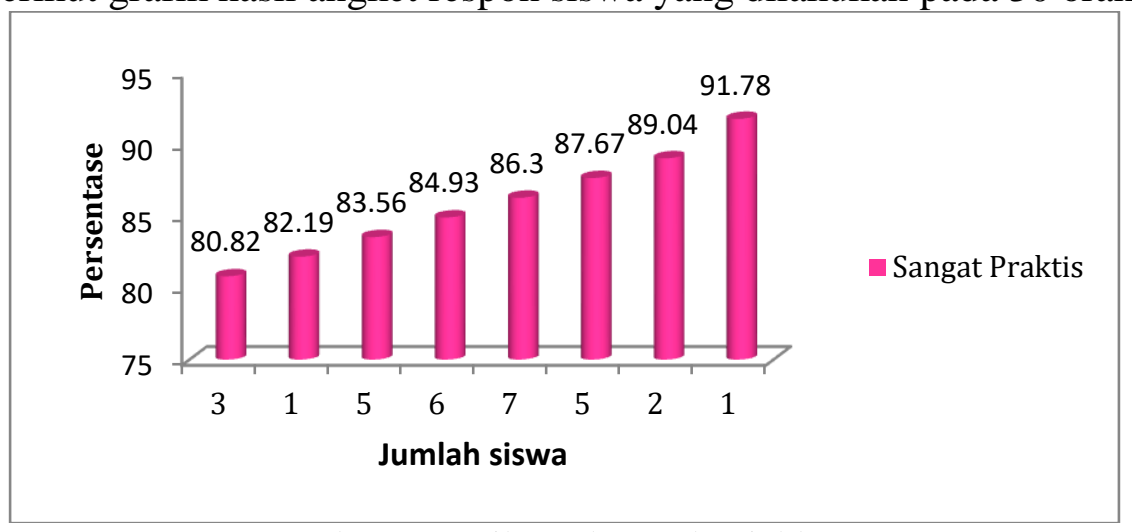

\subsection{Pembahasan}

Gambar 8. Hasil Angket pada Field Tes

Pengembangan LKS ini diawali dari melakukan observasi dan wawancara untuk mencari permasalahan dari LKS yang akan dikembangkan. Kemudian peneliti melakukan analisis kebutuhan siswa meliputi kurikulum karakteristik siswa, selanjutnya peneliti mulai mendesain dan mengembangkan produk LKS yang dinamakan prototype pertama. Pada prototype pertama ini dievaluasi oleh peneliti setelah direvisi dengan dosen pembimbing. Selanjutnya LKS dilakukan expert review dengan 3 orang ahli, bersamaan dengan expert review produk juga dilakukan tahap one to one dengan teman sejawat. Tahap terakhir penilaian pada LKS yaitu small group, dimana pada tahap ini dilakukan oleh siswa dengan jumlah 6 orang siswa untuk melihat kepraktisan produk LKS yang dikembangkan.Tahapan yang paling akhir adalah field test, pada tahap ini LKS sudah bisa digunakan dalam wilayah yang luas.

Dari hasil validasi produk LKS berbasis inkuiri terbimbing berbantuan e-learning yang telah dinilai oleh tiga validator untuk tiga aspek yaitu 1) materi memperoleh nilai sebesar 88,66\% dengan kategori sanat valid; 2) desain mencapai nilai 90,25\% dengan kategori sangat valid dan 3) bahasa diperoleh nilai $86 \%$ dengan kategori sangat valid juga. Untuk tahap one to one yang dilakukan pada tiga orang siswa diperoleh hasil angket sebesar 91,3\% dengan kategori sangat praktis.

Pada tahap small group memperoleh nilai 90,83\% untuk aspek kemenarikan dengan kategori sangat praktis, aspek kemudahan memperoleh nilai $89.99 \%$ dengan kategori sangat praktis dan aspek keterbantuan memperoleh nilai sebesar $92,21 \%$ dengan kategori sangat praktis

Dari 30 siswa yang menjadi subjek penelitian dilihat dari nilai N-Gain pada grafik diatas menunjukkan bahwa sebanyak 18 orang siswa dengan kategori sedang dan 12 orang siswa dengan kategori tinggi. Nilai N-Gain paling tinggi diperoleh sebesar 0,87 dan $\mathrm{N}$-Gain paling rendah diperoleh nilai sebesar 0,6 dengan kategori sedang.

Hasil angket respon siswa setelah menggunakan LKS berbasis inkuiri terbimbing berbantuan e-learning yang diberikan kepada 30 orang siswa memperoleh nilai sebesar $85,81 \%$ dengan kategori sangat praktis. Dilihat dari hasil angket tersebut menunjukkan bahwa respon siswa terhadap produk LKS yang dikembangkan memberikan nilai posif dan dapat diterima oleh siswa.

Berdasarkan penelitian yang dilakukan Utari, Fadhilah, dan Fitriani dengan judul "Pengembangan Lembar Kerja Siswa Praktikum Berbasis Inkuiri Terbimbing Pada Materi Larutan Penyangga Di SMA Negeri 4 Sungai Raya" mengatakan bahwa LKS berbasis inkuiri yang dikembangkan pada analisis kevalidan aspek materi, media dan bahasa menunjukkan nilai validitas masing-masing sebsar 1,00 dengan kriteria sangat tinggi. Hasil analisis kepraktisan respon siswa menunjukkan nilai sebesar 85,65\% dengan kriteria tinggi. Dan hasil kefektifan berdasarkan analisis hasil belajar memperoleh nilai 76,47\% yang telah memenuhi aspek keefektifan (10). Persamaan penelitian tersebut dengan peneliti yaitu sama-sama mengembangkan bahan ajar dan berbasis inkuiri terbimbing. Serta melihat kefektifan LKS vang dikembangkan. Sedangkan perbedaannya Pengembangan LKS Berbasis Inkuiri Terbimbing Berbantuan E-Learning Untuk Meningkatkan Pemahaman Konsep.... Wimpi Calesta, Patricia H.M. Lubis, Sugiarti 
adalah penelitian tersebut pada pelajaran kimia materi larutan penyangga, sedangkan peneliti pada pelajaran fisika dengan materi gerak harmonik sederhana pada bandul.

Hal ini juga sependapat dengan penelitian yang dilakukan oleh Yuliana, Handhika, dan Huriawati dengan judul "Pengembangan Modul IPA Fisika Berbasis Inkuiri Terbimbing Untuk Meningkatkan Pemahaman Konsep Siswa" mengatakan bahwa untuk kevalidan produk yang dikembangkan memiliki kualitas yang baik dan untuk pemahaman konsep memperoleh nilai n-gain sebesar 0,67 dengan kategori sedang (11). Penelitian tersebut memiliki persamaan dengan peneliti yaitu sama-sama mengembangkan bahan ajar dan menggunakan model pembelajaran inkuiri terbimbing serta untuk mengukur pemahaman konsep siswa. Sedangkan perbedaannya yaitu peneliti menggunakan blogspot sebagai media pembelajaran.

Maka, dapat disimpulkan dari beberapa pendapat di atas bahwa LKS yang dikembangkan memiliki kelayakan yang baik, dan juga untuk pemahaman konsep mengalami kenaikan dari sebelum menggunakan LKS yang dikembangkan. Hal ini serupa penelitian yang dilakukan oleh peneliti dengan judul Pengembangan LKS Berbasis Inkuiri Terbimbing Berbantuan E-Learning Untuk Meningkatkan Pemahaman Konsep Pada Siswa. Diperoleh nilai untuk hasil validasi dari ketiga aspek yang nilai bahwa LKS yang dikembangkan sangat valid. Dan untuk hasil pemahaman konsep, mengalami peningkatan dari sebelum dan sesudah menggunakan LKS yang dikembangkan. Sedangkan respon siswa memberikan nilai positif terhadap LKS yang digunakan. Penggunaan blogspot dalam penelitian cukup baik dalam meningkatkan pemahaman konsep pada siswa, walaupun masih ada beberapa kendala yang dihadapi seperti kurang jaringan pada saat mati sehingga membuat blogspot kurang berjalan dengan lancar. Tetapi itu bukan masalah besar, sehingga siswa masih semangat dalam proses pembelajaran.

\section{SIMPULAN DAN SARAN}

\subsection{Simpulan}

Berdasarkan hasil penelitian yang telah dilakukan dan melihat dari data yang diperoleh maka dapat disimpulkan bahwa nilai untuk hasil validasi dari ketiga aspek yang nilai bahwa LKS yang dikembangkan sangat valid. Dan untuk hasil pemahaman konsep, mengalami peningkatan dari sebelum dan sesudah menggunakan LKS yang dikembangkan. Sedangkan respon siswa memberikan nilai positif terhadap LKS yang digunakan.

\subsection{Saran}

Adapun saran dari penelitian ini adalah (1) sebagai bahan acuan untuk guru khususnya guru mata pelajaran fisikan dalam menciptakan susana belajar yang menarik dan sebagai bahan alternatif untuk siswa dalam belajar dan dapat memotivasi siswa; (2) Dapat menambahkan motivasi dan minat belajar siswa khsususnya mata pelajaran fisika sehingga siswa lebih aktif dan kreatif dalam belajar.

\section{DAFTARPUSTAKA}

1. Nurcahyati K, Distrik IW, Wahyudi I. Pengaruh Panggunaan LKS Berbasis Inkuiri Terbimbing Materi Elastisitas Dan Hukum Hooke Terhadap Hasil Belajar Siswa. J Fis dan Pendidik Fis. 2019;2(2):11-9.

2. Masyithah DC, Jufrida, Pathoni H. Pengembangan Multimedia Fisika Berbasis Model Pembelajaran Inkuiri Terbimbing Dengan Menggunakan Adobe Flash CS6 Pada Materi Fluida Dinamis untuk Siswa SMA Kelas XI. J Edukasi Fis. 2017;2(1):51-60.

3. Hanum NS. Kefektifan E-Learning Sebagai Media Pembelajaran (Studi Evaluasi Model Pembelajaran E-Learning SMK Telkom Sandhy Putra Purwokerto). J Pendidik Vokasi. 2013;3(1):90-102.

4. Dewi K, Sadia IW, Ristiati NP. Dengan Setting Inkuiri Terbimbing untuk Meningkatkan. Ejournal Progr Pascasarj Univ Pendidik Ganesha. 2013;3(1):1-11.

5. Irmayanti S, Nugroho MA. Pengembangan Media Pembelajaran Akuntansi Berbasis Web Blog Untuk Meningkatkan Motivasi Belajar Siswa. J Pendidik Akunt Indones. 
2016;14(1):45-54.

6. Wahyudin, Sutikno, Isa A. Keefektifan Pembelajaran Berbantuan Multimedia Menggunakan Metode Inkuiri Terbimbing Untuk Meningkatkan Minat Dan Pemahaman Siswa. J Pendidik Fis Indones. 2010;6(1):58-62.

7. Aqib Z, Jaiyaroh S, Diniati E, Khotimah K. Penelitian Tindakan Kelas. Bandung: Yrama Widya; 2016.

8. Hake RR. Relationship Of Individual Student Normalized Learning Gains In Mechanics With Gender, High-School Physics, And Pretest Scores On Mathematics And Spatial Visualization. In: Physics education research conference. 2002. p. 1-14.

9. Hake RR. Analyzing Change/Gain Scores. Dept of Physics Indiana University; 1999. 1-4 p.

10. Utari WT, Fadhilah R, Fitriani. Pengembangan Lembar Kerja (LKS) Praktikum Berbasis Inkuiri Terbimbing Pada Materi Larutan Penyangga DI SMA Negeri 4 Sungai Raya. Ar-Razi J Ilm. 2018;6(1):69-78.

11. Yuliana T, Handhika J, Huriawati F. Pengembangan Modul IPA Fisika Berbasis Inkuiri Terbimbing Untuk Meningkatkan Pemahaman Konsep Siswa. In: Seminar Nasional Pendidikan Fisika III. Madiun: Universitas PGRI Madiun; 2017. p. 94-101. 